\title{
White Bear Suppression Inventory: translation and cross- cultural adaptation to Brazilian Portuguese
}

\author{
White Bear Suppression Inventory: tradução e adaptação transcultural para a \\ língua portuguesa do Brasil
}

\begin{abstract}
Gabriel Talask, Sabrina Bastos de Freitas, Maria Estela Wildner Rasmussen, Mônica Santos Silva,
\end{abstract} Rafael Thomaz da Costa, Gisele Pereira Dias, Antonio E. Nardi, Marcele Regine de Carvalho

\begin{abstract}
Introduction: Intrusive thoughts may cause a significant level of distress, since some individuals evaluate the content of those thoughts as aversive. Suppression of intrusive thoughts is one of the strategies adopted by these individuals, which increases the level of distress. Suppression of thoughts may be present as one of the factors that maintain different psychological disorders.

Objective: To describe the translation and adaptation into Brazilian Portuguese of the White Bear Suppression Inventory (WBSI), which measures thought suppression.

Methods: Three translations and back-translations were conducted by independent evaluators. Semantic equivalence was assessed and the three versions were evaluated to produce a synthesized version. Comments from participants on the preliminary version of the questionnaire were examined.

Results: We developed a preliminary Brazilian Portuguese version of the WBSI. It was found that most participants understood the descriptions of cognitions given in the translated questionnaire. Conclusion: The use of three different versions of translations and back-translations, discussion of the synthetic version and interaction with the target population have conferred viability to the process of semantic equivalence of the Brazilian Portuguese final version of the WBSI.
\end{abstract}

Keywords: Thought suppression, cross-cultural adaptation, semantic equivalence.

\section{Resumo}

Introdução: Pensamentos intrusivos podem causar um nível significativo de desconforto, uma vez que alguns indivíduos avaliam o conteúdo desses pensamentos como aversivos. A supressão dos pensamentos intrusivos é uma das estratégias adotadas por esses indivíduos, resultando no aumento do nível de desconforto. Supressão de pensamentos pode estar presente como um dos fatores de manutenção de diferentes transtornos psicológicos.

Objetivos: Descrever a tradução e adaptação para o português brasileiro do White Bear Suppression Inventory (WBSI), que avalia a supressão de pensamentos.

Métodos: Três traduções e retrotraduções foram conduzidas por avaliadores independentes. A equivalência semântica foi analisada e as três versões foram avaliadas para produzir uma versão preliminar. Os comentários dos participantes sobre a versão preliminar do questionário foram examinados.

Resultados: Foi desenvolvida uma versão final em português brasileiro do WBSI. Verificou-se que a maioria dos participantes entendeu as descrições das cognições apresentadas no questionário traduzido.

Conclusão: $O$ uso de três versões diferentes de traduções e retrotraduções, discussão da versão preliminar e interação com a população-alvo conferiu viabilidade ao processo de equivalência semântica da versão final brasileira da WBSI.

Descritores: supressão de pensamentos, adaptação transcultural, equivalência semântica 


\section{Introduction}

Intrusive thoughts are common in the daily lives of most people. It is estimated that these thoughts are present in $80-99 \%$ of the general population. ${ }^{1}$ Some individuals evaluate the content of such thoughts as aversive, and attribute some kind of meaning to them, which results in considerable distress. The attempt to suppress these thoughts is one of the possible strategies adopted by these individuals to decrease the level of associated distress. ${ }^{2}$ Nevertheless, the suppression of these thoughts may actually result in an increase in their frequency. ${ }^{3,4}$

Wegner et al. $^{3}$ conducted an experiment to understand the effects and processes of the suppression of thoughts. First, participants were instructed to report everything that came to their mind. Then, they were told to continue with the task, but warned that they could not think about a white bear. If they did, it should be signaled by ringing a bell. In general, the participants failed to suppress the thoughts of the white bear, which were signaled multiple times. The experiment by Wegner et al. $^{3}$ showed that suppressing thoughts may be successful initially but also produces paradoxical effects by increasing the frequency of these thoughts, resulting in a subsequent rebound effect. Recent studies indicate that thought suppression can be found in different psychological conditions, such as depressive disorder, generalized anxiety disorder, panic disorder, addictive behaviors, and it can also be a predictor of obsessive-compulsive disorder. ${ }^{2,4-6}$

Wegner \& Zanakos ${ }^{7}$ developed an instrument, the White Bear Suppression Inventory (WBSI), to examine associations between thought suppression and other measures, as well as to determine whether suppression of thoughts can be understood as a broad risk factor for certain psychological conditions. The WBSI is a Likerttype measurement scale containing 15 items that aim to evaluate the incidence of suppression of thoughts.

The stages of translation and adaptation of the WBSI to the Brazilian Portuguese language are presented in this work. The study aimed to translate and evaluate the semantic equivalence of the WBSI, conducting a pilot study in a Brazilian population sample with different educational levels. Thereby, we sought to develop a preliminary version adapted from the WBSI that can be validated at a later time. A second goal was to evaluate whether the WBSI is applicable to individuals from different educational backgrounds.

\section{Methods}

It is recommended that the cross-cultural adaptation process balance literal translation components from one language to the other and that the adaptation process take into account the cultural context and lifestyle of the target population of the version being developed. ${ }^{8}$ In order to do so, the semantic equivalence process as described by Reichenheim \& Moraes $^{8}$ - was used, as it is one of the main steps for the evaluation of crosscultural equivalence of measurement instruments. This process attempts to use a language that is adapted to the target population. ${ }^{9}$

The process of cross-cultural adaptation occurred in four steps: 1) translation process; 2) back-translation; 3) evaluation of the semantic equivalence of the preliminary Brazilian version; and finally 4) pilot study in which 21 participants from different educational levels were invited a) to fill out the translated and adapted questionnaire, and b) to indicate whether they had faced any difficulty filling it out or whether they had any suggestion to improve the clarity of the items. In step 1, two psychologists and one psychology undergraduate student, all native Brazilians who spoke English as a foreign language, independently translated the original instrument in English into Brazilian Portuguese. Each of the collaborators had studied English to an advanced level. The translators were blind to each other. However, these professionals were chosen because they were familiar with the constructs used in the instrument. They were asked to pay attention to the semantic consistency of the terms and the elaboration of sentences.

In the second step, back-translations into English from a preliminarily translated version were made independently and without knowledge of the original scale by a psychologist, a psychology undergraduate student and an economist, all Brazilians and bilingual in English and Portuguese. In step 3, semantic equivalence evaluation was made by the authors of this study, and the Brazilian Portuguese version was improved based on the three translations and back-translations developed and the comparison with the original instrument. To compose the Brazilian Portuguese version of the questionnaire, the items were incorporated from one of the three versions and may have been minimally modified in order to find the best combination of criteria for semantic equivalence.

After the development of the preliminary Brazilian Portuguese version of the WBSI, step 4 consisted of a pilot study with 21 adult participants, who signed a free and informed consent form and were selected from a convenience sample (Table 1 ) at the Praia Vermelha Campus of Universidade Federal do Rio de Janeiro.

Participants were requested to a) examine the questionnaire and b) report whether each item was clear enough and/or whether they had any suggestions 
to improve the understanding of the instrument. Participants commented on the preliminary version of the questionnaire pointing out the difficulties for understanding, or agreeing fully with that version. Considering these suggestions, the final Brazilian version of the WBSI was developed.

\section{Results and discussion}

The original instrument in English, the translations ( $\mathrm{T} 1, \mathrm{~T} 2$ and $\mathrm{T} 3$ ), respective back-translations ( $\mathrm{R} 1$, R2 and R3) and the preliminary version in Brazilian Portuguese are presented in Table 2.

Table 1 - Demographic characteristics of the pilot study sample

\begin{tabular}{lccc}
\hline Characteristic & Female & Male & Total \\
\hline Schooling & 1 & & \\
$\quad$ Incomplete elementary school & 2 & - & 2 \\
Elementary school & 4 & 5 & 2 \\
High school & 6 & 2 & 8 \\
Higher education & 13 & 8 & 21 \\
Total & & & \\
Age & & & \\
Minimum & 23 & 23 & \\
Maximum & 63 & 60 & \\
Mean \pm standard deviation & $31.92 \pm 11.90$ & $39.88 \pm 13.67$ & \\
\hline
\end{tabular}

Table 2 - Original version, translations, back-translations and preliminary version of the White Bear Suppression Inventory (WBSI)

\begin{tabular}{cl}
\hline Original version & Translations \\
\hline 1. There are things & T1: Existem coisas sobre as quais eu \\
I prefer not to & prefiro não pensar. \\
think about. & T2: Há coisas que eu prefiro não pensar a \\
& respeito. \\
& T3: Há coisas que eu prefiro não pensar.
\end{tabular}

2. Sometimes I wonder why I have the thoughts I do. that I cannot stop.

4. There are images that come to mind that I cannot erase.

5. My thoughts frequently return to one idea.

Back-translations

R1: There are things I would rather not think about.

R2: There are things that I prefer not to think about.

R3: There are things that I rather not think about.

T1: Às vezes me pergunto por que tenho os pensamentos que tenho.

T2: Às vezes eu gostaria de saber porque tenho os pensamentos que tenho.

T3: Às vezes me pergunto por que eu tenho os pensamentos que eu tenho.

R1: Sometimes I wonder why I think the way I do.

R1: Sometimes I wonder why I think the way I do.

R2: Sometimes I would like to know why I have the thoughts I have.

R3: Sometimes I ask myself why I have the thoughts that I have.

R1: I have thoughts which I cannot stop. R2: I have thoughts I cannot control. R3: I have thoughts that I can't stop.

Tenho pensamentos dos quais eu não consigo parar

T2: Eu tenho pensamentos que não consigo controlar.

T3: Eu tenho pensamentos que não consigo parar.

T1: Há imagens que surgem na minha mente que eu não consigo apagar.

T2: Há imagens que vem a minha mente que eu não consigo apagar.

T3: Há imagens que vêm à mente que eu não consigo apagar.

T1: Meus pensamentos frequentemente retornam à uma ideia.

T2: Meus pensamentos frequentemente retornam a uma ideia.

T3: Meus pensamentos frequentemente retornam a uma ideia.

Preliminary version

Há coisas que eu

prefiro não pensar a

respeito.

Às vezes me pergunto por que tenho os pensamentos que tenho. mind that I cannot erase.

R2: There are images that come to my mind that I cannot erase.

R3: There are images that come to mind that I can't erase.

R1: My thoughts constantly go back to the same idea.

R2: My thoughts often return to an idea.

R3: My thoughts frequently come back to an idea.
R1: There are images that pop into my
Há imagens que vem à minha mente que eu não consigo apagar.

Meus pensamentos frequentemente retornam a uma ideia. 


\begin{tabular}{|c|c|c|c|}
\hline Original version & Translations & Back-translations & Preliminary version \\
\hline $\begin{array}{l}\text { 6. I wish I could } \\
\text { stop thinking of } \\
\text { certain things. }\end{array}$ & $\begin{array}{l}\text { T1: Gostaria que eu pudesse parar de } \\
\text { pensar sobre certas coisas. } \\
\text { T2: Eu gostaria de poder parar de pensar } \\
\text { certas coisas. } \\
\text { T3: Eu gostaria de poder parar de pensar } \\
\text { em certas coisas. }\end{array}$ & $\begin{array}{l}\text { R1: I would like to stop thinking about } \\
\text { certain things. } \\
\text { R2: I wish I could stop thinking about } \\
\text { certain things } \\
\text { R3: I would like to be able to stop thinking } \\
\text { about certain things. }\end{array}$ & $\begin{array}{l}\text { Gostaria que eu } \\
\text { pudesse parar de } \\
\text { pensar sobre certas } \\
\text { coisas. }\end{array}$ \\
\hline
\end{tabular}

7. Sometimes my $\mathrm{T} 1$ : Às vezes minha mente acelera tanto mind races so que eu gostaria de poder parar.

fast I wish I T2: Às vezes minha mente está tão

R1: Sometimes my mind gets so worked up I would like to be able to stop it.

Às vezes minha mente acelera tanto que eu could stop it. acelerada que eu gostaria de poder para-la. I would like to stop it.

T3: Às vezes minha mente corre tão rápido R3: Sometimes my mind races so fast that que desejo conseguir parar isso. I wish I could stop it.

gostaria de poder pará-la.

8. I always try to T1: Sempre tento deixar os problemas fora R1: I always try keeping troubles out of put problems da minha mente.

out of mind. T2: Eu sempre tento tirar os problemas da minha cabeça.

T3: Eu sempre tento colocar os problemas para fora da mente.

my mind.

R2: I always try to remove the problems from my mind.

R3: I always try to keep problems out of mind.

9. There are T1: Existem pensamentos que vivem thoughts that "pipocando" em minha cabeça.

keep jumping T2: Existem pensamentos que continuam into my head. pulando dentro da minha cabeça.

pulando dentro da minha cabeça.

dentro da minha cabeça.

R1: There are thoughts that keep popping into my head.

R2: There are thoughts that continue to jump in my head.

R3: There are thoughts that keeping

jumping inside my head.

10. There are things T1: Existem coisas sobre as quais eu tento R1: There are things I try not to think that I try not to não pensar.

think about. T2: Existem coisas que eu tento não pensar a respeito.

about.

R2: There are things that I try not to think about.

T3: Há coisas que eu tento não pensar. $\quad$ R3: There are things that I try not to think about.

11. Sometimes I really wish I could stop

T1: Às vezes eu realmente gostaria de poder parar de pensar.

T2: As vezes eu realmente gostaria de thinking.

parar de pensar.

T3: Às vezes eu realmente desejo

conseguir parar de pensar.

R1: Sometimes I wish I could stop

thinking.

R2: Sometimes I would really like to stop thinking

R3: Sometimes I really wish I could stop thinking.

12. I often do things T1: Com frequência eu faço coisas para me to distract distrair dos meus pensamentos. myself from my T2: Frequentemente faço coisas para me thoughts. distrair dos meus pensamentos.

R1: Frequently I engage on activities to distract myself from my thoughts.

R2: I often do things to distract myself from my thoughts

R3: I frequently do things to distract me T3: Eu frequentemente faço coisas para me distrair dos meus pensamentos.

13. I have thoughts T1: Tenho pensamentos que eu tento that I try to avoid. evitar.

T2: Tenho pensamentos que tento evitar. T3: Eu tenho pensamentos que tento evitar.

14. There are many T1: Existem vários pensamentos que eu thoughts that I have that I don't tell anyone. tenho e não conto para ninguem. T2: Existem muitos pensamentos que tenho e que não conto para ninguém. T3: Há muitos pensamentos que eu tenho que eu não conto a ninguém. from my thoughts.

R1: I have thoughts I try to avoid. R2: I have thoughts that I try to avoid. R3: I have thoughts that I try to avoid.

Sempre tento tirar os problemas da minha cabeça.

Existem pensamentos que vivem

"pipocando" em minha cabeça.

Existem coisas sobre as quais eu tento não pensar a respeito.

Às vezes eu realmente gostaria de poder parar de pensar.

Frequentemente faço coisas para me distrair dos meus pensamentos.

Tenho pensamentos que eu tento evitar.

R1: There are many thoughts I have that tell no one about.

R2: There are many thoughts that I have and I do not tell anyone.

R3: There are many thoughts that I have that I don't tell to anyone.

15. Sometimes I stay busy just to keep thoughts from intruding on my mind.

T1: Às vezes eu me mantenho ocupado(a), apenas para impedir que pensamentos invadam a minha mente.

T2: Às vezes eu permaneço ocupado apenas para evitar que pensamentos intrusos invadam a minha mente. T3: Às vezes eu fico ocupado apenas para manter os pensamentos entretidos na minha mente.

R1: Sometimes I keep myself busy just so I can stop thoughts from invading my mind.

R2: Sometimes I keep myself busy just to prevent intruder thoughts from getting into my mind.

R3: Sometimes I get busy just trying to keep thoughts distracted in my mind.
Existem muitos pensamentos que eu tenho e não conto para ninguém.

Às vezes eu me mantenho ocupado(a), apenas para impedir que pensamentos invadam a minha mente. 
The versions revised by the translators coincided with each other in items 5, 12 and 13 . Item 15 presented the most significant difference among them, due to a translation error of the word "intruding," which was translated as "entretidos" (which means "entertained") by the third translator. The other items showed small differences, which were considered not to alter the overall meaning of the sentences.

Regarding the back-translations, items 10 and 13 coincided with each other. Only item 15 presented a significant difference, due to the above mentioned translation error. The remaining items had similar back-translations, without any interference in their meaning.

Comparing the translations with the original version, only item 15 obtained non-congruent versions regarding the meaning of the terms. It should be noted that in item 9, where the expression "keep jumping" appears, a literal translation - "pulando" (which means "jumping") - and also an expression closer to the Brazilian Portuguese language - "pipocando" (which means "popping") - were suggested. Nevertheless, these two terms do not diverge in terms of meaning equivalence of the expressions in both languages. As for the comparison of the back-translations with the original version, only item 15 presented a discrepancy due to the misunderstanding in the translation of one of its terms. The other items did not present differences in the overall meaning of the sentences.

All the items incorporated in the preliminary version coincided with at least one of the three translation versions. In cases of different words that had the same meaning in the Brazilian Portuguese translations, the authors chose to keep the option that was closest to the literal translation of the original version. Thus, in the preliminary Brazilian Portuguese version of the WBSI, in items 4, 7, 8 and 10 , the choice for the final translation was due to closeness to the literal meaning of the sentence in the translation from English to Brazilian Portuguese, as there was no semantic divergence between the options used for translation. In item 9, as mentioned above, the choice for "existem pensamentos que vivem 'pipocando' em minha cabeça" was due to the judgment that this expression would be more intelligible and usual than "existem pensamentos que vivem pulando em minha cabeça", due to the fact that the expression "keep jumping" in the English language resembles the Brazilian Portuguese expression "pipocar" ("popping").

The purpose of this pilot study was to test the comprehensiveness of the preliminary version and to verify the need for possible modifications in any word or sentence that could hinder comprehension. The ultimate goal was to test the possibility of using the questionnaire with a wide range of individuals, with cultural differences and in different educational contexts.

Participants reported that the questionnaire presented was easy to understand, but some suggestions were given. In item 3, four female participants with higher education degrees and one male participant with high school degree reported that the sentence "tenho pensamentos dos quais eu não consigo parar" seemed a bit confusing, even though they understood its meaning. They suggested "tenho pensamentos dos quais não deixo de pensar," "tenho pensamentos dos quais eu não consigo parar de ter," "tenho pensamentos dos quais eu não consigo evitar," "tenho pensamentos dos quais eu não consigo me livrar," "tenho pensamentos dos quais eu não consigo interromper." Due to the recurring feedback, the suggestions given were considered in the development of the final version (Table 3 ) of the WBSI in Brazilian Portuguese. Therefore, the choice of "tenho pensamentos dos quais eu não consigo interromper" for the final version is justified due to the greater approximation of this version to the literal sense of the phrase in the translation from English to Brazilian Portuguese.

Item 5 ("meus pensamentos frequentemente retornam a uma ideia") also received feedback from three female and two male participants with higher education degrees, for the same reasons as in item 3. Four of these participants suggested that "meus pensamentos frequentemente retornam a uma mesma ideia" would be easier to understand. For this reason, this was chosen as the final version.

A female participant with higher education degree commented that, in item 4, the term "apagar" (which means "erase") could be replaced with "esquecer" (which means "forget"), but the authors decided to maintain the item unchanged, respecting the option that was closest to the original.

In item 9, two participants, both with higher education degrees, suggested changing the term "pipocando" to "brotando" and "surgindo". Also in this case, the authors chose to keep the item unchanged, respecting the translation option that was closest to the original.

Thus, in the final version of the WBSI, changes were made only to items 3 and 5, according to feedback from the participants, as presented in Table 3. The other items remained unchanged. 
Table 3 - Items changed according to feedback from participants

\begin{tabular}{|c|c|c|c|}
\hline Original version & Translations & Backtranslations & Brazilian version \\
\hline $\begin{array}{l}\text { 3. I have thoughts } \\
\text { that I cannot } \\
\text { stop. }\end{array}$ & $\begin{array}{l}\text { T1: Tenho pensamentos dos quais eu não } \\
\text { consigo parar. } \\
\text { T2: Eu tenho pensamentos que não } \\
\text { consigo controlar. } \\
\text { T3: Eu tenho pensamentos que não } \\
\text { consigo parar. }\end{array}$ & $\begin{array}{l}\text { R1: I have thoughts which I cannot stop. } \\
\text { R2: I have thoughts I cannot control. } \\
\text { R3: I have thoughts that I can't stop. }\end{array}$ & $\begin{array}{l}\text { Tenho pensamentos } \\
\text { que não consigo } \\
\text { interromper. }\end{array}$ \\
\hline $\begin{array}{l}\text { 5. My thoughts } \\
\text { frequently return } \\
\text { to one idea. }\end{array}$ & $\begin{array}{l}\text { T1: Meus pensamentos frequentemente } \\
\text { retornam à uma ideia. } \\
\text { T2: Meus pensamentos frequentemente } \\
\text { retornam a uma ideia. } \\
\text { T3: Meus pensamentos frequentemente } \\
\text { retornam a uma ideia. }\end{array}$ & $\begin{array}{l}\text { R1: My thoughts constantly go back to the } \\
\text { same idea } \\
\text { R2: My thoughts often return to an idea. } \\
\text { R3: My thoughts frequently come back to } \\
\text { an idea }\end{array}$ & $\begin{array}{l}\text { Meus pensamentos } \\
\text { frequentemente } \\
\text { retornam a uma } \\
\text { mesma ideia. }\end{array}$ \\
\hline
\end{tabular}

\section{Conclusion}

The translation and cross-cultural adaptation process of the WBSI was compatible with the current recommendations in the literature. Its final Brazilian Portuguese version was obtained through a careful process of translation and back-translation, study of semantic equivalence and a pilot study for evaluation of the understanding and clarity of the items in the questionnaire. It was verified that the participants understood the descriptions of the cognitions exposed in the Brazilian Portuguese questionnaire. Then, final adjustments were made based on their feedbacks. Thus, this version seems to be adequate in relation to the process of semantic equivalence and may be applicable to individuals of different educational levels, as observed in the sample.

It is important to emphasize that for a research instrument to be used, it must be valid and reliable, as well as sensitive and specific. The processes of cross-cultural adaptation and semantic equivalence are fundamental for the validation of a questionnaire, but they are only the initial stage. Future studies should test the factorial structure and consistency of the Brazilian Portuguese version of the WBSI here presented and evaluate its convergent and divergent validity.

\section{Disclosure}

No conflicts of interest declared concerning the publication of this article.

\section{References}

1. Zucker BG, Craske MG, Barrios V, Holguin M. Thought action fusion: can it be corrected? Behav Res Ther. 2002;40:653-64.

2. Magee JC, Harden KP, Teachman BA. Psychopathology and thought suppression: a quantitative review. Clin Psychol Rev. 2012;32:189-201.

3. Wegner DM, Schneider DJ, Carter SR, White TL. Paradoxical effects of thought suppression. J Pers Soc Psychol. 1987;53:5-13.

4. Abramowitz JS, Tolin DF, Street GP. Paradoxical effects of thought suppression: a meta-analysis of controlled studies. Clin Psychol Rev. 2001;21:683-703.

5. Fehm L, Margraf J. Thought suppression: specificity in agoraphobia versus broad impairment in social phobia? Behav Res Ther. 2002:40:57-66.

6. Moss AC, Erskine JA, Albery IP, Allen JR, Georgiou GJ. To suppress, or not to suppress? That is repression: controlling intrusive thoughts in addictive behaviour. Addict Behav, 2015;44:65-70.

7. Wegner DM, Zanakos S. Chronic thought suppression. J Pers. 1994;62:615-40.

8. Reichenheim ME, Moraes CL. Operacionalização de adaptação transcultural de instrumentos de aferição usados em epidemiologia. Rev Saude Publica. 2007;41:665-73.

9. Herdman M, Fox-Rushby J, Badia X. A model of equivalence in the cultural adaptation of HRQoL instruments: the universalist approach. Qual Life Res. 1998;7:323-35.

\section{Correspondence:}

Gabriel Talask

Av. Venceslau Braz, 71, Botafogo

22290-140 - Rio de Janeiro, RJ - Brazil

E-mail: gabrieltalask@gmail.com 